\title{
SEVERE HYPONATREMIA AND THE SYNDROME OF INAPPROPRIATE SECRETION OF ANTIDIURETIC HORMONE (SIADH) ASSOCIATED WITH FLUOXETINE
}

\section{Case report}

\author{
Carlos Alexandre Twardowschy', Cristina Buselatto Bertolucci², \\ Cleverson de Macedo Gracia ${ }^{3}$, Marta Ângela de Souza Brandão ${ }^{4}$
}

\begin{abstract}
Hyponatremia is a significant complication of treatment with serotonin selective reuptake inhibitors (SSRI). We describe a case of a 53-year-old woman that was started on fluoxetine $20 \mathrm{mg} /$ day for depression. Nine days later, the patient started with weakness, nausea, pro g ressing to confusion, inapetence and vomit. Three hours later she became unresponsive and had a generalized seizure. She was brought to our emergency service. On admission, the patient was normovolemic, without focal motor deficits, but had mild generalized muscle rigidity and Babinski's sign bilaterally. Serum sodium was 105 $\mathrm{mmol} / \mathrm{L}$, serum osmolality, $220 \mathrm{mmol} / \mathrm{L}$, and urinary osmolality, $400 \mathrm{mmol} / \mathrm{L}$. The other laboratory exams, chest X-ray, cere b rospinal fluid and cranium tomography were normal. She was found to have fluoxetineinduced SIADH and it was descontinued. We started the hyponatremia correction and, in 5 days, the mental status of the patient gradually retu rned to a normal baseline, paralleling the resolution of her hyponat remia, without re c u rrence. Hyponatremia and SIADH should be considered if a patient experiences deterioration in his or her clinical condition while taking SSRI. The use of SSRI antidepressants should be remembered in the differential diagnosis of drug-induced hyponatremia.
\end{abstract}

KEY WORDS: antidepressive agents, fluoxetine, inappropriate ADH syndrome.

\begin{abstract}
Hiponatremia grave e síndrome da secreção inapropriada de hormônio antidiurético (SSIHAD) associada com fluoxetina: relato de caso

RESUMO - A hiponatremia é complicação significativa do tratamento com inibidores seletivos da recaptação da serotonina (ISRS). Descrevemos o caso de uma paciente de 53 anos de idade que iniciou uso de fluoxetina $20 \mathrm{mg} /$ dia para depressão. Nove dias depois, a paciente apresentou fraqueza, náusea, progredindo para confusão, inapetência e vômitos. Três horas depois ela tornou-se irresponsiva e teve uma crise convulsiva generalizada. Foi então trazida ao nosso serviço de emergência. Na admissão, a paciente estava n o rmovolêmica, sem déficits motores focais, mas apresentava leve rigidez muscular generalizada e sinal de Babinski bilateralmente. O sódio sérico era $105 \mathrm{mmol} / \mathrm{L}$, osmolaridade sérica, $220 \mathrm{mmol} / \mathrm{L}$, e osmolaridade urinária, $400 \mathrm{mmol} / \mathrm{L}$. Os outros exames laboratoriais, Raio-X do pulmão, líquido cefalorraqueano e tomografia do crânio eram normais. Ela foi diagnosticada como tendo SSIHAD induzida por fluoxetina sendo esta descontinuada. Nós iniciamos a correção da hiponatremia e, em 5 dias, o estado mental da paciente gradualmente ret o rnou ao normal, paralelamente a resolução da hiponatremia. SSIHAD e hiponat remia devem ser consideradas em um paciente que apresenta deterioração de sua condição clinica quando estiver em uso de ISRS. O uso de antidepressivos ISRS deve ser lembrado no diagnóstico diferencial de hiponatremia induzida por drogas.
\end{abstract}

PALAVRAS-CHAVE: antidepressivos, fluoxetina, síndrome da secreção inapropriada de hormônio antidiurético, inibidores de recaptação de serotonina.

De partment of Internal Medicine \& Department Neurology of Nossa Senhora das Graças Hospital, Curitiba, PR, Brazil: ${ }^{1}$ Internal Medicine Resident; ${ }^{2}$ Psychiatry Resident, Clinics Hospital, Federal University of Paraná; ${ }^{3}$ Neurologist; ${ }^{4}$ Intensivist.

Received 19 May 2005, received in final form 28 July 2005. Accepted 23 September 2005.

Dr. Carlos Alexandre Twardowschy - Rua Desembargador Vieira Cavalcanti 777 / Sob 3 - 80510-090 Curitiba PR - Brasil. E-mail: carlos.alexandre.tw@bol.com.br 
The syndrome of inappropriate secretion of antidiuretic hormone (SIADH) is an important, underrecognized and serious complication of the selective serotonin reuptake inhibitors (SSRIs), like fluoxetine. Primary care physicians may not be aware of this potential adverse effect. However, hyponatraemia complicating SSRI antidepressant use has now become widely reported ${ }^{1}$.

We describe a case of a woman presenting with severehyponatremia and SIADH strongly associated with the use of fluoxetine.

\section{CASE}

An 53-year-old woman was seen in an emergency department for evaluating a chest pain and dyspnea for the past two months. The patient also reported associated forgetfulness, decreasing energy, anhedonia, insomnia, anxiety and irritability for the past four months. No psychotic symptoms were identified. She had no familiar cardiovascular risk. She was been treated for systemic arterial hypertension for the past eight years, and last year was on losar$\tan (100 \mathrm{mg} /$ day) plus hydrochlorothiazide $(25 \mathrm{mg} / \mathrm{day})$. Acute myocardial infarct was ruled out and renal function was normal, except for sodium (131 mmol/L). The patient was discharged for a cardiologist evaluation and she was started on fluoxetine ( $20 \mathrm{mg} /$ day) and continued with another drugs.

Nine days later, the patient started with weakness and nausea in the morning. At night of the same day she became confused, was unable to stand or feed herself, and had one episode of vomit. Three hours later she became unresponsive and had a generalized seizure, during approxi-

Table. Laboratory evaluation during hyponatremia correction.

\begin{tabular}{|c|c|c|c|c|c|}
\hline Exam/day & 1 & 2 & 3 & 4 & 5 \\
\hline Hemoglobin $(g / d L)$ & 14.4 & 14.6 & 13.5 & 13.1 & \\
\hline Leucocytes (per $\mathrm{mm}^{3}$ ) & 14.130 & 12.140 & 7.830 & 6.160 & \\
\hline Band forms (\%) & 12 & 10 & 7 & 1 & \\
\hline Platelets (per $\mathrm{mm}^{3}$ ) & 329.000 & 310.000 & 282.000 & 287.000 & \\
\hline INR * & 1.1 & & & & \\
\hline Glucose (mg/dL) & 266 & 124 & 114 & & 112 \\
\hline Serum Ca (mg/dL) & 8.4 & 8.2 & & & 8.5 \\
\hline Serum $\mathrm{Mg}(\mathrm{mmol} / \mathrm{L})$ & 1.7 & 2.1 & 2.4 & & 2.1 \\
\hline Serum $\mathrm{Na}(\mathrm{mmol} / \mathrm{L})$ & 105 & 114 & 130 & 130 & 138 \\
\hline Serum K (mmol/L) & 2.9 & 3.2 & 2.9 & 3.8 & 3.9 \\
\hline Urinary $\mathrm{Na}(\mathrm{mmol} / \mathrm{L})$ & 70 & 27 & & & 68 \\
\hline Urinary $\mathrm{K}(\mathrm{mmol} / \mathrm{L})$ & 20 & 15 & & & \\
\hline Serum osmolality (mOsm/L) & 220 & 261 & & & 288 \\
\hline Urinary osmolality (mOsm/L) & 400 & 328 & & & 224 \\
\hline Urea (mg/dL) & 14 & 10 & & & 8 \\
\hline Creatinin (mg/dL) & 0.6 & 0.7 & 0.8 & 0.7 & 0.7 \\
\hline AST (U/L) & 29 & & & & \\
\hline ALT (U/L) & 30 & & & & \\
\hline Total bilirubin $(\mathrm{mg} / \mathrm{dL})$ & 1.0 & & & & \\
\hline $\mathrm{pH}$ & 7.49 & & & & \\
\hline $\mathrm{pCO}_{2}$ & 33 & & & & \\
\hline $\mathrm{HCO}_{3}$ & 25 & & & & \\
\hline $\mathrm{pO}_{2}$ & 74 & & & & \\
\hline TSH & 0.59 & & & & \\
\hline
\end{tabular}

*INR, international normalized ratio. 


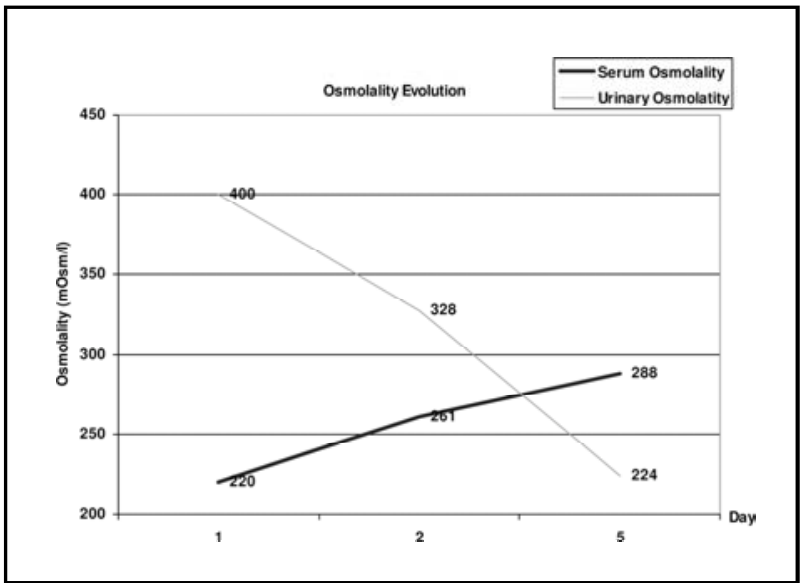

Graph. Urinary and serum osmolality evaluation.

mately 1 minute, followed by sleepness. After the attack she was brought to our emergency service. On admission the patient was lethargic, with impaired attention and alertness, but she was normovolemic and without focal motor deficits. Her blood pressurewas $210 / 100 \mathrm{mmHg}$. She had mild generalized muscle rigidity, Babinski's sign bilaterally and increased deep tendon reflex. Laboratory evaluation is show in Table. She was performed a cranium tomography and a cerebrospinal fluid analysis, that were normal. Thyroid stimulation hormone (TSH) level was within n o rmal limits. No indications of pneumonia were found on chest X-Ray. Abdomen ultrasonography was normal too.

The hyponatremia was believed to be secondary to fluoxetine-induced SIADH and the SSRI was discontinued. Her systolic blood pressu rewas controlled with oral nifedipine. Fluids were restricted to $1000 \mathrm{~mL} /$ day and, because of the severity of symptoms hypertonic saline solution was given plus $80 \mathrm{mg}$ of intravenous furosemide. The hypokal emia was also corrected with $200 \mathrm{mmol} \mathrm{K+/day.} \mathrm{With} \mathrm{improve-}$ ment of her hyponatremia, the patient became more alert; generalized muscle rigidity, Babinski's sign and increased deep tendon reflex disappears, but her condition subsequently worsened. She had intermittent difficulty in speaking, naming objects, also had memory deficits and psychomotor slowness. A brain magnetic resonance (MRI) revealed bilateral symmetric hyperintense lesions in the basal ganglia, temporal lobe and hippocampal formation (Figure ). The serum $\mathrm{Na}+$ continued to return to normal over the next few days. The patient's speech cleared and her mentation returned to the premorbid level in five days, paralleling the resolution of her hyponatremia (Graph). The fluid restriction was discontinued without recurrence of hyponatremia. After few days she was discharged home without any deficits.

\section{DISCUSSION}

Hyponatremia is a significant complication of treatment with SSRI antidepressants. It occurs in the majority of cases (79\%) within the first 3 weeks of treatment and in all cases within 10 weeks $^{2}$. Although

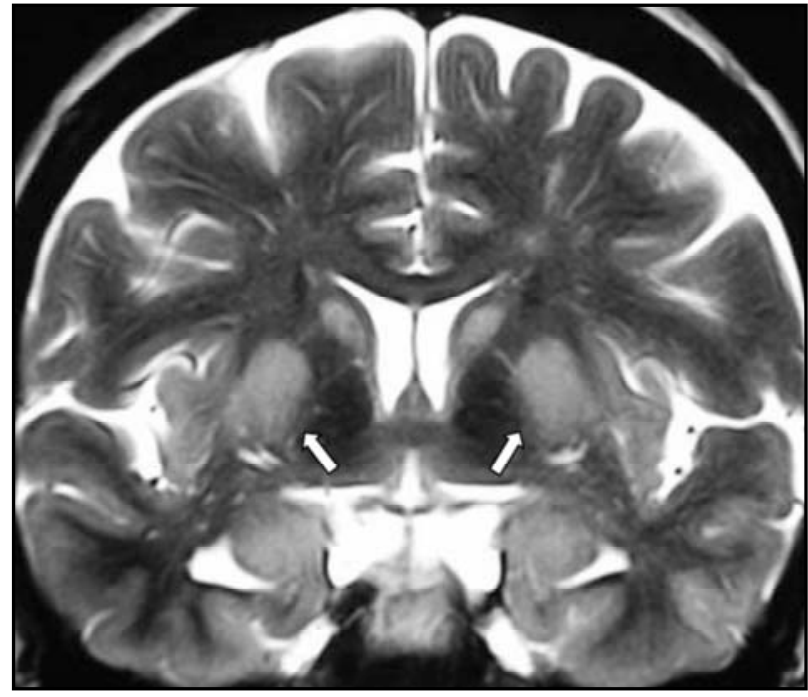

Figure. Brain MRI: The coronal "FLAIR" image shows bilateral symmetric hyperintense lesions in the basal ganglia, temporal lobe and hippocampal formation. (Observation: the arrows are showing the lesions.)

most cases involve fluoxetine, this may reflect higher utilization of this SSRI rather than an increased risk of hyponatremia ${ }^{1}$. This adverse effect occurs in elderly people at an incidence of 4.7 cases/1000/year (6.3/1000 for fluoxetine and 3.5/1000 for paroxetine), but it could happen in all ages.

The mechanism of hyponatraemia is thought to be the syndrome of inappropriate secretion of antidiu retic hormone. The essential criteria for the diagnosis of SIADH are: 1) Decreased effective osmolality of the extracellular fluid (plasmatic osmolality $<275$ $\mathrm{mOsm} / \mathrm{Kg}$ ); 2) Inappropiated urinary concentration (urinary osmolality $>100 \mathrm{mOsm} / \mathrm{Kg}$, with a normal renal function) at some level of hypoosmolality; 3) Clinical euvolemia; 4) Elevated urinary sodium excretion; 5) Absence of other potential causes of euvolemic hypoosmolality: hypothyroidism, hypocortisolism and diuretic use ${ }^{3}$.

Hypoosmolality is primarily associated with a broad spectrum of neurologic manifestations, ranging from mild, nonspecific symptoms (e.g., headache, nausea) to more significant disorders (e.g., disorientation, confusion, obtundation, focal neurologic deficits, and seizures). This neurologic symptom complex has been termed hyponatremic encephalopathy and primarily reflects brain edema resulting from osmotic water shifts into the brain because of decreased effective plasma osmolality. Significant neurologic symptoms usually do not occur until serum [ $\mathrm{Na}^{+}$] falls below 125 $\mathrm{mEq} / \mathrm{L}$, and the severity of symptoms can be rough- 
ly correlated with the degree of hypoosmolality. However, individual variability is marked, and for any single patient, the level of serum $\left[\mathrm{Na}^{+}\right]$at which symptoms appear cannot be predicted with great accuracy. In the most severe cases of hyponatremic encephalopathy, death results from respiratory failure after tentorial cerebral herniation and brainstem compression. Clinical studies also have suggested that menst ruating women and young children may be part i cularly susceptible to the development of neurologic morbidity and mortality during hyponatremia, especially in the acute postoperative setting ${ }^{3}$.

It has been unclear whether hyponatremia that develops from treatment with one SSRI will recur if a second one is introduced. Challenge with the same $\mathrm{d}$ rug resulted in recurrence of the hyponatremia in $66,7 \%$. Challenge with another SSRI from the same class was also reported. Exposures to other agents known to be associated with hyponatremia or SIADH, concomitant with SSRIs, were reported. The most commonly implicated drugs were diuretics (30\%), neuroleptics $(15,1 \%)$, and narcotics $(6,7 \%)^{1}$.

Serotonin-mediated effects on $5-\mathrm{HT}$, and $5-\mathrm{HT}_{1 \mathrm{c}}$ receptors have been shown to induce release of $A D H$. However, the potency of these effects varies greatly between the different SSRIs. The effect of various psychotropic drugs on neurotransmitters has been speculated to contribute to excess ADH secretion; however, the exact mechanism of SSRI-induced SIADH remains unknown'.

Elderly people do experience a decrease in total body water, renal blood flow, glomerular filtration rate, and renal tubular concentrating and diluting capacity. These age-related alterations in water metabolism may render the elderly patient susceptible to this complication. In this age group, the maximal diluting and concentrating capacity of the kidney is i m p a i red, and ADH secretion may be slightly incre ased. In addition, the ADH response to osmolar stimuli has been shown to be greater in elderly people. This increased osmosensitivity may increase the risk for SIADH' ${ }^{1}$.

Identification of patients who are at increased risk for development of hyponatremia is essential to the safe and successful treatment of their psychiatric illnesses. Reduced weight and/or increased age are important risk factors. These risk factors could both act by causing a reduction in drug clearance which, for a given dose, will result in higher concentrations ${ }^{2}$. A case-control study of the risk factors for the devel- opment of hyponatremia in psychiatric inpatients shown that diuretic, fluoxetine, tricyclic antidepressants and calcium antagonists were all associated with the development of this complication ${ }^{4}$.

Typically, full recoverymay require several days (up to a week) and an adequate "washout" period is required before commencing alternative antidepressant therapy. The product information recommends washout periods of two weeks for sertraline and paroxetine and five weeks for fluoxetine. Youngest patients may have shortest recovery time ( 2 and 3 days) than the oldest and the median time is 8 days $(2-14)^{5}$. Our 53 -years-old patient had fully recovery in 3 days. Geriatric patients may be at risk for increased morbidity from prolonged recovery ${ }^{6}$.

The lesions seen in brain MRI was compatible with osmotic demyelination syndrome precipitated by correction of the hypoosmolar state. Initial low serum sodium concentration in this case, because of diure tic use, certainly was a predisposing factor. Like we demonstrate, the most commonly associated drug causing this syndrome are thiazide diuretics $(30 \%)^{1}$, therefore the physician that first initiated fluoxetine should have monitored her sodium concentration closely or changed for another antidepressant because of hydrochlorothiazide use.

Patients, in particular elderly patients, should have their serum sodium concentration monitored, especially in the early stages of treatment with SSRI. Hyponatremia and SIADH should be considered if a patient experiences deterioration in his or her clinical condition while taking an SSRI, regardless of the duration of treatment. The use of SSRI antidepressants should be remembered in the differential diagnosis of druginduced hyponatremia.

\section{REFERENCES}

1. Liu BA, Mittmann N, Knowles SR, Shear NH. Hyponatremia and the synd rome of inappropriate secretion of antidiuretic hormone associated with the use of selective serotonin reuptake inhibitors: a review of spontaneous reports. Can Med Assoc J 1996;155:519-527. Erratum in: Can Med Assoc J 1996;155:1043.

2. Wilkinson TJ, Begg EJ, Winter AC, Sainsbury R. Incidence and risk factors for hyponatraemia following treatment with fluoxetine or paroxetine in elderly people. Br J Clin Pharmacol 1999;47:211-217.

3. Schrier RW. Diseases of the kidney and urinary tract. 7th Edition. Philadelphia: Lippincott Williams \& Wilkins, 2001:2519-2527.

4. Siegler EL, Tamres D, Berlin JA, Allen-Taylor L, Strom BL. Risk factors for the development of hyponatremia in psychiatric inpatients. Arch Intern Med 1995;155:953-957.

5. Kazal LA Jr, Hall DL, Miller LG, Noel ML. Fluoxetine-induced SIADH: a geriatric occurrence? J Fam Pract 1993;36:341-343.

6. Bouman WP, Pinner G, Johnson H. Incidence of selective serotonin reuptake inhibitor (SSRI) induced hyponatraemia due to the syndrome of inappropriate antidiuretic hormone (SIADH) secretion in the elderly. Int J Geriatr Psychiatry 1998;13:12-15. 